\title{
The Effect of China's New Circular Collective Forest Tenure Reform on Household Non-Timber Forest Product Production in Natural Forest Protection Project Regions
}

\author{
Yang Ren ${ }^{1}$, Jari Kuuluvainen ${ }^{2}$ (i), Anne Toppinen ${ }^{2}$ (D), Shunbo Yao ${ }^{1, *}$, Sami Berghäll ${ }^{2}$, \\ Heimo Karppinen ${ }^{2}$ (D), Caixia Xue ${ }^{1}$ and Liu Yang ${ }^{1}$ \\ 1 Research Center for Resource Economics and Environment Management, \\ College of Economics and Management, Northwest A\&F University, No. 3 Taicheng Road, Yangling 712100, \\ China; yang.ren@helsinki.fi (Y.R.); xiaoxueacc@126.com (C.X.); yangliu6661@126.com (L.Y.) \\ 2 Department of Forest Sciences, University of Helsinki, P.O. Box 27, Helsinki 00014, Finland; \\ jari.kuuluvainen@helsinki.fi (J.K.); anne.toppinen@helsinki.fi (A.T.); sami.berghall@helsinki.fi (S.B.); \\ heimo.karppinen@helsinki.fi (H.K.) \\ * Correspondence: yaoshunbo@nwafu.edu.cn; Tel.: +86-029-8708-1291
}

Received: 22 March 2018; Accepted: 2 April 2018; Published: 5 April 2018

\begin{abstract}
The implementation of China's natural forest protection project (Protection Project) in 1998 changed households' forestry production modes in project regions, and China's new circular collective forest tenure reform (Tenure Reform) has been implemented since 2003 with the goal of motivating household forestry production and increasing household income from forests. Policymakers expect that Tenure Reform could also stimulate households to engage in non-timber forest products (NTFPs) production in Protection Project regions. However, only a few studies have investigated the effect of Tenure Reform on household NTFP production in Protection Project regions. To fill this gap, we built an integrative conceptual framework and estimated a corresponding structural equation model (SEM) using survey data from 932 households in Protection Project regions in southwestern China. In our research framework, there are four factors, including household characteristics, labour and social capital, forestland characteristics, and the Tenure Reform, affecting household NTFP production. The results substantiate that Tenure Reform has had a significant positive effect on household NTFP production. Additionally, household and forestland characteristics have promoted household NTFP production, but quantitatively less than Tenure Reform. This report can be used to inform the government that future investment in Tenure Reform still needs to be enhanced, and policy enforcement still needs to be strengthened.
\end{abstract}

Keywords: households; non-timber forest products production; collective forest tenure reform; natural forest protection project; structural equation model; China

\section{Introduction}

China has forcibly implemented the Natural Forest Protection Project (Protection Project) since 1998, with the aim of protecting natural ecosystems [1]. Varying the degree of logging bans in different regions is the most critical policy instrument used by the program [2]. By 2016, over 30 million hectares of natural forests in 18 out of 34 provincial-level administrative regions had engaged in the Protection Project [3]. In these regions, the Protection Project has dramatically changed the way in which households utilize forests and other natural resources, leading to decreased timber incomes for farmers [4]. Consequently, farmers in many Protection Project regions have gradually begun shifting 
to non-timber forest products (NTFPs) on forestlands to compensate losses in timber production opportunities [5]. Household NTFP production has also been encouraged by policymakers [6]. However, NTFP production is not thriving in all Protection Project regions [7].

NTFP production is considered to be a more sustainable way of utilizing forests in Protection Project regions than wood production [8,9]. Previous literature on NTFP has concluded that NTFP production provides a range of local-level sustainable livelihood benefits to households and communities [10-14]. Additionally, as NTFP production can increase the economic value of forests, farmers are more incentivized to manage forests both more intensively and also sustainably $[15,16]$. Further, earlier studies have indicated that NTFP production is beneficial for forest conservation in ecological preservation areas worldwide [17-19]. Knowing which factors motivate household NTFP production - especially in Protection Project regions-is therefore of great importance.

In 2003, with the goal of motivating household forestry production and increasing household incomes from forests, China launched a new circular collective forest tenure reform (Tenure Reform). The reform was implemented in two phases: the main reform and the supplementary reform. In the main reform, forest property rights and the use rights of most collective forestland were devolved to households with legal forestland certificates. This stage was mainly completed by 2012 [5]. After this, almost $99 \%$ of all collective forestland in China was assigned to households [3]. During the supplementary reform, a bundle of additional rights concerning forestland was entitled to households, including the right to transfer, inherit, and mortgage the entitled forestland. Additionally, during the second stage, production training and consultation services were offered to households by local forestry bureaus. The supplementary reform also encourages and supports households to establish forestry cooperatives to facilitate household forestry activities. In 2017, the supplementary reform was still underway nationally $[3,20]$. A wide range of necessary favourable conditions for forestry production was provided to households during the Tenure Reform implementation process. However, households in Protection Project regions are not allowed to conduct timber harvesting. Thus, both of these Tenure Reform phases in Protection Project regions may generate significant incentives for households to become involved in NTFP production. Given that the second phase of Tenure Reform is still ongoing on a large scale, it is of great importance to clarify the performance of Tenure Reform from the perspective of its stimulating effect on household NTFP production.

Although some studies have investigated the effects of certain factors influencing household NTFP production [21-24], to the best of our knowledge, the effect of Tenure Reform has not been studied in the previous literature. Furthermore, the policy-relevant effects of various factors-including Tenure Reform - have not been studied in an integrated analytic framework [25-27]. Incorporating all the a priori important factors into a unified framework is therefore necessary. In this way, we can obtain information on the effect of Tenure Reform on household NTFP production, along with other essential factors affecting production, including household characteristics [28], labour and social capital [29], and forestland characteristics [30]. We accomplished this by using a structural equation modelling (SEM) methodology and using household survey data from Sichuan province in southwestern China. Our study can help in understanding the structure of the influencing effects of Tenure Reform and the role of other factors and their magnitudes. The results could enable us to understand whether the policy instruments of Tenure Reform work effectively or not, and to help policymakers and project implementers further design and implement Tenure Reform and other national policies promoting socio-economic development in China and elsewhere.

\section{Conceptual Framework}

To study the impacts of Tenure Reform and other factors on household NTFP production, we first need to identify the influence pathways and then define the functional structure and determinants of these factors along each pathway.

We assume that farmers aim to maximize their families' utilities, but the strategies are affected by their household characteristics [31]. Based on previous literature, men as household heads appear 
to focus more often on off-farm jobs than women do in rural China [32]. In addition, certain studies have found that Chinese female household heads (registered in the Chinese Household Registration System) play more important roles in NTFP production and tend to manage forests more than men. For example, a study by Zhang and Owiredu [33] concluded that female-headed households tend to invest more in silviculture compared to male-headed households. The reason is that the matrilineal mode of inheritance plays a vital role within forestry production in the study area. Low-income households are more willing to devote more effort to NTFP production because these households rely more on farm income [34]. Minority nationalities are usually also low-income households in China, and also tend to rely more on NTFP production as a source of livelihood [35].

Opportunity cost could be considered as an essential factor affecting household NTFP production. High opportunity costs from forestry production usually tend to decrease farmers' forestry production and therefore also the production of NTFP [36]. Additionally, the available labour force may constrain forestry production. Part-time farming is a universal phenomenon in China [37], and for many farmers, off-farm employment is an important part of a family's income in rural China. Therefore, households with relatively high off-farm incomes are less motivated to allocate labour to the forestry sector than households with relatively high forest income [38]. In contrast, households with a larger share of forestry income are normally more incentivized to become involved in NTFP production [39]. Thus, we propose:

Hypothesis 1 (H1). Household characteristics are one type of decisive factor affecting household NTFP production strategies.

According to existing studies, household labour and social capital are positively associated with a household's ability and intention to engage in NTFP production [40,41]. Age, education level, and experience in forestry work are the main indicators for assessing the forestry labour capital [42]. The social security system in rural China is relatively weak and incomplete [43]. Thus, forestland often serves as a livelihood insurance for elderly farmers [44]. As a result, elderly farmers normally tend to rely more on forestry production [45]. Certain studies also concluded that educational background is a key determinant of the degree of dependence on NTFP production [46]. For higher-educated farmers, it is easier to acquire information concerning technologies and the market, and then adopt more efficient production patterns. Farmers with more experience in forestry also often have more chances of mastering skills that lead to better forestry production performance [47]. Additionally, a household's social capital affects its production and marketing efficiency. This is mainly because households with a higher level of social capital usually have better access to information concerning marketing approaches supporting forestry production [48]. Thus, based on the above argumentation, we hypothesize:

Hypothesis 2 (H2). Household's labour and social capital are associated with household NTFP production.

Various forestland characteristics can be assumed to lead to different forestry production profiles [48]. Larger forestland areas can induce economies of scale, so a higher rate of economic return per unit of forestland would be expected from larger forestland areas [49]. The fragmented ownership of forestland may therefore pose an adverse effect on NTFP production [50]. To give a few examples, households in rural China usually tend to plant economic forests on more fertile land within proximity to home, plant timber and fuelwood forests on less fertile forestland far away from home, and cultivate traditional Chinese medicine materials on less deep and more fertile land, etc. Thus, households tend to use inputs more intensively on closer, less deep and more fertile forestland compared to distant, sloping, and less fertile lands [51]. Based on previous literature, we hypothesize:

Hypothesis 3 (H3). Better forestland characteristics are positively associated with more intense NTFP production by households. 
The primary objective of implementing Tenure Reform is to motivate households' forestry investments and multifunctional forest production, and thus improve their standard of living [52]. Tenure Reform and its support mechanisms can offer farmers well-defined user and other rights to forestland entitled to them, and policies that support household forestry production. Therefore, this reform can dramatically change household patterns of forestry production [53].

Being familiar with Tenure Reform is a prerequisite for households to be aware of their rights concerning the forestland entitled to them and then to efficiently utilize the supportive policies [54]. This is because households' understanding of Tenure Reform can update household attitudes and customs towards forest rights and NTFP [31]. As a part of Tenure Reform policies, local governments support the establishment of forestry cooperatives. Aiming to help households produce and market forestry products professionally and effectively, these forestry cooperatives usually offer qualified production materials, professional training, consultation services, and efficient marketing channels to households that voluntarily join forestry cooperatives [34]. Local forestry bureaus also offer farmers training and consultation services. Clarifying the user and other rights concerning forestland is an important part of Tenure Reform policies, and is likely to induce more investment incentives [55]. Previous studies have revealed that forestland certifications could be a catalyst for increasingly rapid development of the transfer market of rural forestland and for promoting forest investments [56]. All of the abovementioned developments should have strengthened the likely positive impact that Tenure Reform has on household NTFP production in Protection Project regions. So, we postulate:

\section{Hypothesis 4 (H4). Tenure Reform would motivate household NTFP production.}

Based on the hypotheses above, the total impact of factors affecting household NTFP production is an aggregate of four types of effects independently generated through corresponding pathways. We summarize our analytic framework in Figure 1. By testing all the effects of the identified affecting pathways, this integrative analytical framework can be used to assess the impacts Tenure Reform has on household NTFP production.



Figure 1. Hypothetical structural model of the factors affecting household non-timber forest product (NTFP) production.

In Figure 1, the elliptical boxes represent the four abovementioned aspects of the influencing factors. They are treated as independent latent variables affecting household NTFP production, which is the dependent latent variable. These four pathways represent the hypothesized relationships between household characteristics, labour and social capital, forestland characteristics, Tenure Reform, and household NTFP production. 


\section{Materials and Methods}

\subsection{Data Source}

The data used in our study were gathered from Meishan municipality, southwest of Sichuan province in southwestern China. The study area was selected because its ecological and economic conditions are fairly well representative of the regions targeted by Protection Project and Tenure Reform, and it is one of the earliest Protection Project pilot sites where Tenure Reform was launched later, aiming to motivate farmers to establish economic forests and become involved in NTFP production. Local governments consider developing NTFP production in an effective way in order to motivate forestry investments and alleviate poverty. Most importantly, 76\% of the forestland in Meishan became part of the Protection Project and the forest coverage rate is 30\%. Before this, timber revenues accounted for a quite large portion of household revenue [57]. With timber harvesting becoming largely banned, households did not have much incentive to invest in forestry. Forestry production and household forestry revenues dropped dramatically in Meishan after the implementation of the Protection Project.

However, along with Tenure Reform, a great deal of collective forest was devolved to households, which led an increasing number of households to invest in NTFP production. By the end of 2016, Meishan had 110,328 hectares of land in NTFP production compared to 57,814 hectares in 2003. The income from NTFP became the central household forestry revenue instead of timber harvesting revenues [57].

The data for empirical analyses were collected during August, September, and October of 2017 using structured personal interviews. On average, the investigators interviewed each chosen respondent for approximately 90 minutes to acquire the data needed in the questionnaires. Data collection was financially supported by the Chinese National Natural Science Foundation. Household surveys were implemented using stratified random sampling. Six administrative towns were initially selected from the town list of Meishan based on the geographic coverage of the Tenure Reform program, the distribution of farmers' incomes, and the NTFP production engagement. Next, villages and households were selected randomly from each of the administrative townships. Finally, six villages from each township and 30 households from each village were included in our study.

Enumerator training for all investigators, pre-tests including ca. 60 sample households, and two focus group discussions involving 20 representative households in two sample villages were conducted before the main survey. While the questionnaires were refined over time by improving their intelligibility and the practicability during the preparations above before the main survey, they all contained data needed in our study, including information on household characteristics, labour and social capital, forestland characteristics, Tenure Reform, and household NTFP production. In addition, we refined the survey strategies during data collection in order to ensure that the surveys were valid. Aiming to reflect the current state of household production, we asked respondents to carefully recall all relevant information back to 2012. Whenever possible, data entries were compared to local socioeconomic statistics from official sources to check their accuracy. In general, responses appeared to deviate from the government statistics by no more than $15 \%$, suggesting a sufficient level of reliability. The descriptive statistics of the observed variables of four aspects of influencing factors and household NTFP production are given in Table 1. Table A1 displays the specific definition of each measurement item. 
Table 1. Operationalization of variables in the hypothetical model and descriptive statistics of household survey data.

\begin{tabular}{|c|c|c|c|c|c|}
\hline $\begin{array}{c}\text { Latent } \\
\text { Variables }\end{array}$ & Description of Observed Variables & $\begin{array}{l}\text { Variable } \\
\text { Codes }\end{array}$ & Response Options & Mean & Std. dev. \\
\hline \multirow{5}{*}{$\begin{array}{l}\text { Household } \\
\text { Characteristics }\end{array}$} & Gender of household head & GEND & Male $=0 ;$ Female $=1$ & 0.16 & 0.21 \\
\hline & Minority or not & MINO & Yes $=0 ;$ No $=1$ & 0.81 & 0.44 \\
\hline & Opportunity cost & OPPO & $\begin{array}{c}\text { Very high }=1 ; \text { High }=2 ; \\
\text { Middle }=3 ; \text { Low }=4 ; \text { Very low }=5\end{array}$ & 3.76 & 1.42 \\
\hline & Forest labour force (person-days) & FLAB & $1=1 ; 2=2 ; 3=3 ; 4=4 ; \geq 5=5$ & 2.03 & 0.81 \\
\hline & $\begin{array}{l}\text { Ratio of forestland-based income to } \\
\text { total household income (\%) }\end{array}$ & INRA & $\begin{array}{c}\leq 5=1 ;(5,10]=2 ;(10,15]=3 \\
(15,20]=4 ;>20=5\end{array}$ & 3.28 & 0.97 \\
\hline \multirow{5}{*}{$\begin{array}{l}\text { Labour and } \\
\text { Social Capital }\end{array}$} & Mean of age (years) & MAGE & $\begin{array}{c}\leq 30=1 ;(30,40]=2 ;(40,50]=3 \\
(50,60]=4 ;>60=5\end{array}$ & 3.24 & 1.05 \\
\hline & Mean of education (years) & MEDU & $\begin{array}{c}0=1 ;(0,6]=2 ;(6,9]=3 ;(9,12]=4 ; \\
>12=5\end{array}$ & 2.39 & 0.97 \\
\hline & $\begin{array}{l}\text { Mean experience of forestry } \\
\text { production (years) }\end{array}$ & EXPE & $\begin{array}{c}\leq 3=1 ;(3,5]=2 ;(5,7]=3 \\
(7,10]=4 ;>10=5\end{array}$ & 3.54 & 0.81 \\
\hline & $\begin{array}{l}\text { Number of valid access to } \\
\text { information concerning forestry } \\
\text { production }\end{array}$ & ACCE & $\begin{array}{c}\leq 2=1 ;(3,4]=2 ;(4,5]=3 ;(5,6]=4 ; \\
>6=5\end{array}$ & 2.06 & 0.34 \\
\hline & Number of marketing channels & MARK & $\begin{array}{c}\leq 2=1 ;(3,4]=2 ;(4,5]=3 ;(5,6]=4 ; \\
>6=5\end{array}$ & 3.58 & 0.87 \\
\hline \multirow{4}{*}{$\begin{array}{l}\text { Forestland } \\
\text { Characteristics }\end{array}$} & Scale (ha) & SCAL & $\begin{array}{c}\leq 0.33=1 ;(0.33,1.00]=2 \\
(1.00,2.00]=3 ;(2.00,3.33]=4 \\
>3.33=5\end{array}$ & 3.21 & 0.94 \\
\hline & $\begin{array}{l}\text { Fragmented ownership of forestland } \\
\text { (ha/plot) }\end{array}$ & FRAG & $\begin{array}{c}\leq 0.07=1 ;(0.07,0.20]=2 ; \\
(0.20,0.33]=3 ;(0.33,0.67]=4 ; \\
>0.67=5\end{array}$ & 3.81 & 1.45 \\
\hline & Soil fertility & FERT & $\begin{array}{l}\text { Very barren }=1 ; \text { Barren }=2 ; \\
\text { Middle }=3 ; \text { Fertile }=4 ; \\
\text { Very fertile }=5\end{array}$ & 2.31 & 1.38 \\
\hline & Distance from home to forestland & DIST & $\begin{array}{l}\text { Very } \text { far }=1 ; \text { Far }=2 ; \text { Middle }=3 ; \\
\quad \text { Near }=4 ; \text { Very near }=5\end{array}$ & 2.91 & 1.17 \\
\hline \multirow{4}{*}{$\begin{array}{l}\text { Tenure } \\
\text { Reform }\end{array}$} & $\begin{array}{c}\text { Familiarity with Tenure Reform } \\
\text { policies and rights concerning } \\
\text { forestland }\end{array}$ & INFO & $\begin{array}{c}\text { Very unfamiliar }=1 ; \\
\text { Unfamiliar }=2 ; \text { Middle }=3 ; \\
\text { Familiar }=4 ; \text { Very familiar }=5\end{array}$ & 3.74 & 1.35 \\
\hline & Membership of forestry cooperatives & COOP & $\mathrm{No}=0 ; \mathrm{Yes}=1$ & 0.68 & 0.52 \\
\hline & $\begin{array}{l}\text { Access to training and consultation } \\
\text { service }\end{array}$ & TRCO & $\begin{array}{c}\text { Very poor }=1 \text {; Poor }=2 ; \\
\text { Middle }=3 ; \text { Sufficient }=4 ; \\
\text { Very sufficient }=5\end{array}$ & 3.24 & 1.02 \\
\hline & Forestland certificates & CERT & $\begin{array}{l}\text { Not in possession of forestland } \\
\text { certificates = 0; Possessing } \\
\text { forestland certificates }=1\end{array}$ & 0.89 & 0.26 \\
\hline \multirow{4}{*}{$\begin{array}{l}\text { Household } \\
\text { NTFP } \\
\text { Production }\end{array}$} & $\begin{array}{c}\text { Income from NTFP production per } \\
\text { year (thousand yuan) }\end{array}$ & INCO & $\begin{array}{c}\leq 5=1 ;(5,10]=2 ;(10,20]=3 \\
(20,30]=4 ;>30=5\end{array}$ & 2.48 & 1.12 \\
\hline & $\begin{array}{c}\text { Capital investment per hectare per } \\
\text { year (thousand yuan) }\end{array}$ & CAPI & $\begin{array}{c}\leq 0.2=1 ;(0.3,0.4]=2 ;(0.4,0.5]=3 \\
(0.5,0.6]=4 ;>0.6=5\end{array}$ & 3.21 & 1.29 \\
\hline & $\begin{array}{l}\text { Labour input per hectare per year } \\
\text { (person-days) }\end{array}$ & LABO & $\begin{array}{c}\leq 5=1 ;(5,10]=2 ;(10,15]=3 \\
(15,20]=4 ;>20=5\end{array}$ & 3.51 & 1.34 \\
\hline & $\begin{array}{l}\text { Ratio of forestland involved to total } \\
\text { household forestland (\%) }\end{array}$ & PROP & $\begin{aligned} \leq 0.2= & 1 ;(0.3,0.4]=2 ;(0.4,0.5]=3 \\
& (0.5,0.6]=4 ;>0.6=5\end{aligned}$ & 4.62 & 1.37 \\
\hline
\end{tabular}

Note: (1) All the zero values are included when calculating the mean and std. (2) $\$ 1=6.33$ yuan based on exchange rate in August 2017.

We obtained 932 valid responses out of 1080 conducted interviews after excluding questionnaires with outliers and missing values. Due to the volume of data, it is possible to shed some light on Tenure Reform implementation in the study area. Based on the degree and quality of the responses, although $6 \%$ of households were completely unaware of Tenure Reform, most farmers were quite familiar with the Tenure Reform policy. The proportion of households that had joined forestry cooperatives was relatively high (68\%). Local forestry bureaus and other social organizations offered some production training and consultation services, but this remained insufficient. Most households in the study area had engaged in Tenure Reform, but approximately 10\% did not have legal usufruct certificates for their entitled forestland. 


\subsection{Estimation Approach}

The structural equation model (SEM) approach was used to test the derived hypotheses concerning the factors affecting household NTFP production. SEM contains two parts, a measurement model and a structural model, thus combining confirmatory factor analysis and regression analysis.

The dataset of our study was reasonably fit for path modelling. While traditional approaches normally first construct summated variables of the latent variables and next estimate the sub-model paths [58], SEM enables simultaneously estimating the direct effects of independent latent variables on household NTFP production, and also the contributions of observed variables on each latent variable $[59,60]$. Furthermore, both the reliability and validity of the observed variables can be measured by model specification tests, which is important in the present context. In general, because SEM is a hybrid estimation approach, it enables the advancement of our understanding of the relationship between the latent variables through the combination of theoretical hypotheses in Section 2 and empirical knowledge [58].

\section{Results}

\subsection{Model Specification Tests}

We tested model validity using a standard procedure of model specification tests, including individual item reliability analysis, convergent validity analysis, discriminant validity analysis, and confirmatory factor analysis [61]. In the following, we briefly report the test results before reporting the results of the final SEM estimation.

\subsubsection{Individual Item Reliability Analysis}

Individual item reliability can be used to measure the consistency, stability, and reliability of estimation results. Cronbach's $\alpha$ is customarily used to test individual item reliability, and its acceptable value should be at least above 0.70 [60]. Based on the output from SPSS 22.0, our individual item reliability analysis is at a satisfactory level, ranging between 0.706 and 0.824 (See Table 2).

Table 2. Results of individual item reliability and convergent validity analysis.

\begin{tabular}{cccc}
\hline Latent Variables & Cronbach's $\boldsymbol{\alpha}$ & Construct Reliability & Average Variance Extracted \\
\hline Household Characteristics & 0.756 & 0.849 & 0.553 \\
Labour and Social Capital & 0.824 & 0.723 & 0.519 \\
Forestland Characteristics & 0.791 & 0.726 & 0.581 \\
Tenure Reform & 0.706 & 0.810 & 0.507 \\
Household NTFP Production & 0.819 & 0.834 & 0.502 \\
\hline
\end{tabular}

\subsubsection{Convergent Validity Analysis}

Convergent validity analysis is used to measure the internal consistency of a measurement model. It includes two parts: construct reliability (CR) and average variance extracted (AVE) analyses. A CR of 0.6 or higher indicates good reliability [62]. The measurement model is considered to have adequate convergence if AVE is higher than 0.5 [63]. Based on the test results in Table 2, the CR and AVE from household characteristics, labour and social capital, forestland characteristics, Tenure Reform, and household NTFP production are all at acceptable levels. This suggests that our measurement model has acceptable convergent validity.

\subsubsection{Discriminant Validity Analysis}

Discriminant Validity Analysis is used to illustrate whether latent variables differ from each other to an acceptable extent. According to Fornell and Larker [64], the squared correlations between latent 
variables should be smaller than the AVEs of the latent variables. The correlation matrix in Table 3 reveals that the discriminant validity of our model is adequate.

Table 3. Comparisons of squared correlations between latent variables and the average variances extracted (AVEs).

\begin{tabular}{cccccc}
\hline Latent Variables & $\begin{array}{c}\text { Household } \\
\text { Characteristics }\end{array}$ & $\begin{array}{c}\text { Labour and } \\
\text { Social Capital }\end{array}$ & $\begin{array}{c}\text { Forestland } \\
\text { Characteristics }\end{array}$ & $\begin{array}{c}\text { Tenure } \\
\text { Reform }\end{array}$ & $\begin{array}{c}\text { Household NTFP } \\
\text { Production }\end{array}$ \\
\hline $\begin{array}{c}\text { Household } \\
\text { Characteristics } \\
\text { Labour and }\end{array}$ & 0.553 & 0.226 & 0.519 & & \\
$\begin{array}{c}\text { Social Capital } \\
\text { Forestland }\end{array}$ & 0.219 & 0.402 & 0.581 & & \\
$\begin{array}{c}\text { Characteristics } \\
\text { Tenure Reform }\end{array}$ & 0.183 & 0.207 & 0.384 & 0.507 & \\
$\begin{array}{c}\text { Household NTFP } \\
\text { Production }\end{array}$ & 0.109 & 0.201 & 0.241 & 0.273 & 0.502 \\
\hline
\end{tabular}

\subsubsection{Confirmatory Factor Analysis}

Except for the standardized factor loading of the observed variable "Minority or not", which exceeds 1.0 with negative error variance, the other standardized factor loadings are greater than 0.6 and statistically significant. We therefore modified the estimation model by deleting the "Minority or not" variable [65]. After modification, we observed no negative error variances or standardized factor loadings exceeding 1.0 related to any coefficients in the final SEM.

Table 4 gives the results of the goodness-of-fit indices of our model using the SPSS 22 software program with the AMOS tool. The generalized least-squares (GLS) estimator was used to conduct the computation of the model estimation because it can handle the SEM with latent variables having multiple indicators, not all of which are continuous. This means that the inclusion of dichotomous and ordered polytomous observed variables will be allowed in the SEM estimation, although the normality assumptions of observed variable distributions are less strict.

The goodness-of-fit indices include normed Chi-square, root-mean-square residual (RMR), root-mean-square error of approximation (RMSEA), goodness-of-fit index (GFI), adjusted GFI (AGFI), relative GFI (RFI), comparative GFI (CFI), and normed GFI (NFI). The criterion values of these goodness-of-fit indices are also shown in Table 4 [66]. Table A2 shows the covariance matrix of the measurement items. The values of the covariance range from 0.040 to 2.017. In general, the results imply that the measurement model fits the survey data satisfactorily.

Table 4. Goodness-of-fit indices of the final model.

\begin{tabular}{ccccccccc}
\hline Goodness-of-fit Indices & $\chi \mathbf{x} / \mathbf{d f}$ & RMR & RMSEA & GFI & AGFI & RFI & CFI & NFI \\
\hline Criterion & $<3$ & $<0.05$ & $<0.05$ & $>0.90$ & $>0.90$ & $>0.90$ & $>0.90$ & $>0.90$ \\
Value & 2.065 & 0.039 & 0.043 & 0.971 & 0.916 & 0.941 & 0.947 & 0.939 \\
\hline
\end{tabular}

x2/df: The normed Chi-square; RMR: root-mean-square residual; RMSEA: root-mean-square error of approximation; GFI: goodness-of-fit index; AGFI: adjusted goodness-of-fit index; RFI: relative goodness-of-fit index; CFI: comparative goodness-of-fit index; NFI: normed goodness-of-fit index.

\subsection{Hypotheses Testing}

The estimation results are shown in Figure 2. Each path between ellipses in Figure 2 corresponds to a hypothesis made in Section 2. 


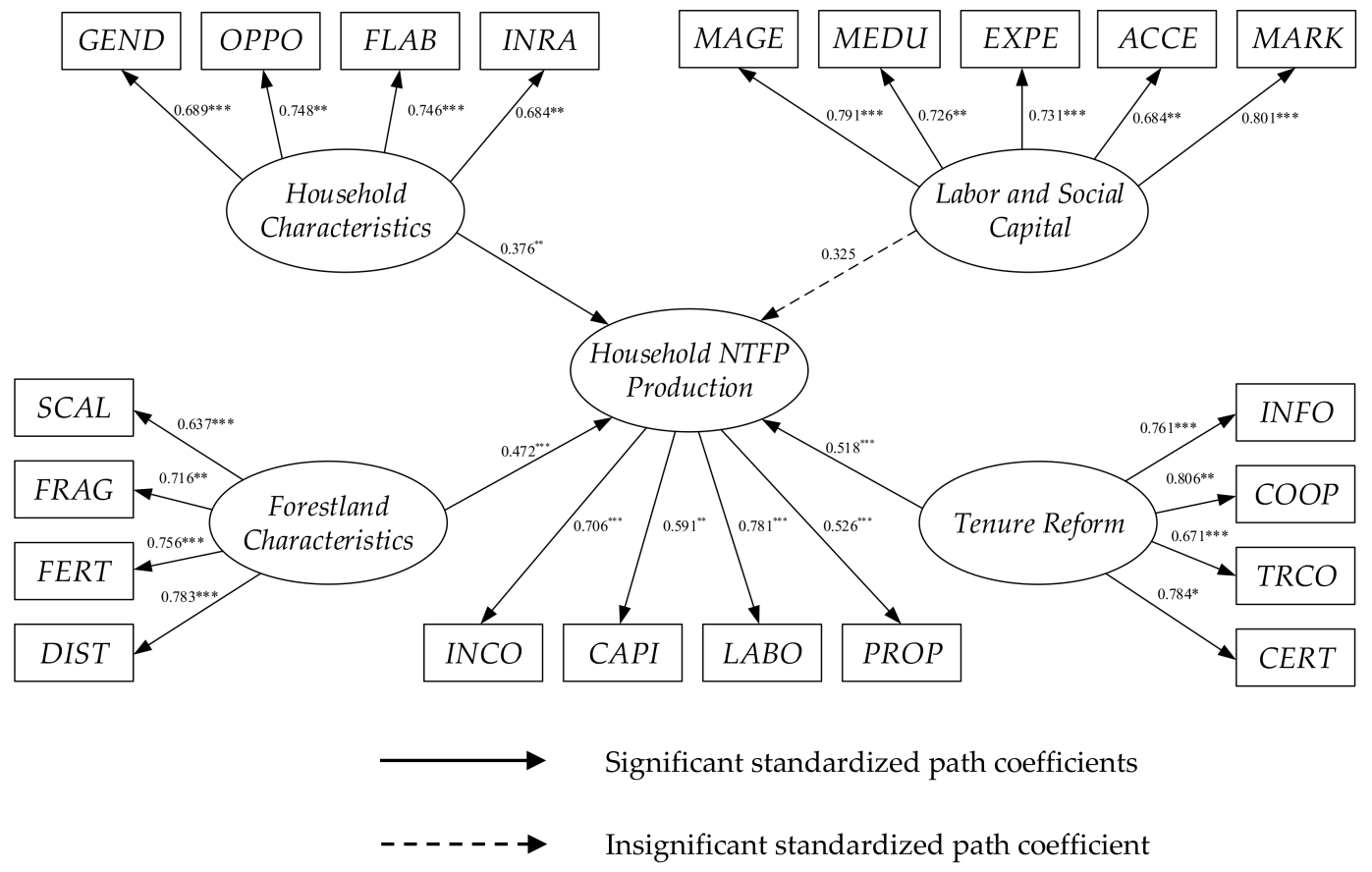

Figure 2. Estimation results of the final structural equation modelling (SEM) model ( $n=932)$. Note: *, $* *$, and ${ }^{* *}$ denote a statistical significance at the $10 \%, 5 \%$, and $1 \%$ levels, respectively. To save space, measurement errors are not included.

We evaluated the study hypotheses using the standardized path coefficients between four exogenous latent variables and the endogenous latent variable. The higher the standardized path coefficient, the stronger the hypothesized relationships between the latent variables in the conceptual model. Table 5 shows the standardized path coefficients, the corresponding $t$-values, and the results of the hypotheses testing.

Table 5. Results of the structural model.

\begin{tabular}{lcccc}
\hline \multicolumn{1}{c}{ Path } & Expected Sign & $\begin{array}{c}\text { Standardized } \\
\text { Path Coefficient }\end{array}$ & $t$-value & Inference \\
\hline $\begin{array}{l}\text { H1: Household } \\
\text { Characteristics } \rightarrow \text { Household NTFP }\end{array}$ & + & $0.376^{* *}$ & 2.627 & Supported \\
$\begin{array}{l}\text { Production } \\
\text { H2: Labour and Social }\end{array}$ & & & & \\
$\begin{array}{l}\text { Capital } \rightarrow \text { Household NTFP } \\
\text { Production }\end{array}$ & + & 0.325 & 1.839 & Not Supported \\
$\begin{array}{l}\text { H3: Forestland } \\
\text { Characteristics } \rightarrow \text { Household NTFP }\end{array}$ & + & & & Supported \\
$\begin{array}{l}\text { Production } \\
\text { H4: Tenure Reform } \rightarrow \text { Household }\end{array}$ & + & $0.472 * * *$ & 3.816 & Supported \\
NTFP Production & + & $0.518^{* * *}$ & 3.914 & S \\
\hline
\end{tabular}

Note: ${ }^{* *}$ and ${ }^{* * *}$ denote statistical significance at the $5 \%$ and $1 \%$ levels, respectively.

\section{Discussion and Conclusions}

Based on the results above, our main general conclusion is thus that household NTFP production can be explained with a four-dimensional SEM model consisting of family characteristics, labour and social capital, forestland characteristics, and Tenure Reform. The standardized path coefficients of 
household characteristics, forestland characteristics, and Tenure Reform towards household NTFP production are significant. This is in line with three of our four hypotheses.

Although significant, the influence of household characteristics is relatively lower than that of forestland characteristics and Tenure Reform. Our results reveal that households' financial conditions and employment opportunities are still fundamental and decisive prerequisites of forestry production. However, the standardized path coefficient of households' labour and social capital on household NTFP production is not significant. Thus, hypothesis 2 is not supported. Two possible reasons may be behind this: firstly, NTFP production is currently still labour-extensive without much advanced technology and skills involved [67], and a well-educated forest labour force with versatile experience is therefore not an essential part in the process of household NTFP production; secondly, although household social capital varies to a large degree, households without good social capital can still easily gain access to the main marketing approaches [68]. Additionally, the assemblers of NTFP, as rational-economic units, are receptive to any qualified products. Thus, the facilitating effect of households' labour and social capital on NTFP production may not be significant. Sufficient forestland area and fertile soil quality are prerequisites of forestry production. Forestland characteristics therefore affect household NTFP production decisions.

The results show that "Tenure Reform" has the greatest influence on household NTFP production, with 0.518 absolute value of the coefficient, followed by "Forestland Characteristics" at 0.472 and "Household Characteristics" at 0.376. Based on these results, Tenure Reform appears to be the most important factor influencing household NTFP production. A possible reason for this is that farmers are motivated to engage in the investments through forestry training and consultation services offered by local governments aiming to facilitate NTFP production during the implementation of Tenure Reform. In addition, Tenure Reform encourages farmers, local governments, village collective committees, and social-economic subjects to set up forestry cooperatives that offer farmers training, productive technology, and marketing services, etc. All of these services offer NTFP production support to households familiar with Tenure Reform, and thus are able to effectively utilize the policies. Another reason is the Tenure Reform issued household forestland certificates, which guarantee households the right to use, transfer, mortgage, and inherit the issued forestland. The expected income from NTFP production is projected to be higher because of this, which is a vital factor motivating household involvement in NTFP production. We should note that the households' rights of mortgaging the forestland could decrease the production capital constraint of NTFP production to some extent. In general, as a result of the abovementioned reasons, farmers are more willing to construct more productive facilities and conduct long-term investments for NTFP production.

Our results corroborate several findings of prior research [30,69], but also contrast with some others. Our study confirms that the devolution of collective forestland is a strong incentive, and a tool to improve NTFP production. However, certain earlier studies have claimed that the fragmented ownership of forestland induced by forest tenure decentralization would impede the investments in NTFP production [26,55]. This difference may be due to NTFP production being very labour-intensive, so mechanization is not suitable or very necessary for local NTFP in certain regions [53]. This implies that Tenure Reform cannot decrease the economies of scale in NTFP production in these regions. Based on this study, although Tenure Reform has induced the fragmented ownership of forestland, household NTFP production incentives have not decreased. The question of whether the fragmented forestland ownership dampens the incentives of NTFP production or not may vary across different regions, and the outcome depends on the varieties of NTFP available. Promotion and support policies should therefore be adjusted to appropriately match the specific region.

The results from our study confirm that Tenure Reform can significantly motivate households to engage in NTFP production. Thus, as an important part of Tenure Reform supporting mechanisms, the training offered by Tenure Reform during its implementation could to some extent be beneficial to household NTFP production. However, certain studies from other regions in China have concluded that passing on NTFP production skills between generations is a practical and sufficient way for 
households to have an adequate command of NTFP production skills [70]. These studies have concluded that the training offered by forestry bureaus and cooperatives for NTFP production does not appear to efficiently function $[30,69]$. Therefore, regional differences exist concerning the effects of training, and in the future, more attention should be given to various regions and NTFP varieties to further verify this divergence.

Our findings indicate some potential avenues for Tenure Reform to facilitate and better motivate households to engage in NTFP production in the future. Policymakers and project implementers could try to facilitate easier access to information concerning Tenure Reform policies for households and offer more supportive policies to the development of forestry cooperatives. In addition, because forestland certification - as a main element of Tenure Reform — can contribute to defining forest property boundaries clearly and to strengthening the bundle of household forestland rights [7], issuing legal forestland certificates firmly and entirely on a large scale in the future may be a good policy measure for government to take.

Although the significant role of NTFP in rural development has been acknowledged for over 20 years [71], the sustainable management of forests has been traditionally focused on timber production in many countries around the world. Similarly, Tenure Reform and its support mechanisms mostly pay attention to timber production. Thus, there is still insufficient special policy support for NTFP production, although we found that Tenure Reform has a significantly positive effect on household NTFP production. This is also because NTFP have unique production characteristics relative to those of timber. For example, some NTFP have short harvesting periods and products perish soon after harvesting. Additionally, their frequent, uncontrollable, and illegal harvest may have adverse effects on the forest ecosystem [72]. Therefore, the government could formulate additional supportive measures directly for NTFP production when developing second-stage Tenure Reform policies in the future. Additionally, multifunctional sustainable forest management is required for the improved harvesting and sustainable use of NTFP. Further, in addition to Tenure Reform, policymakers and households could generate a reasonable NTFP production strategy through scientific analysis (e.g., SWOT analysis [73]) based on relevant factors from the internal and external environment. For example, they could pay close attention to the natural resources endowment, institutional environment, and market demand and competition, etc.

To date, to the best of our knowledge, no study has modelled the relationship between Tenure Reform and household NTFP production using an integrated analysis framework, and therefore our results confirm and highlight the importance of Tenure Reform on NTFP production. This report can be used to inform the government that future investment in Tenure Reform still needs to be enhanced and the policy enforcement still needs to be strengthened.

In this article, we formulated an integrative framework to assess factors affecting household NTFP production using SEM and data collected from Sichuan province in China during 2017. The results provide solid support for three out of our four theoretical hypotheses, and, in particular, our study highlights the enhancement effect of Tenure Reform on household NTFP production in Protection Project regions. Specifically, the estimated results show that household characteristics, forestland characteristics, and Tenure Reform in particular, significantly affect household engagement in NTFP production to varying degrees.

Our findings are based on the regional data available to us. Thus, this may constrain the generalizability of our conclusions. Future research for enriching our understanding of NTFP could potentially proceed with larger-scale and long-term empirical research. Additionally, future research should pay attention to formulating additional supportive measures and fostering a proper institutional environment which could ensure the sustainable use of NTFPs when developing second-stage Tenure Reform policies.

Acknowledgments: We wish to thank the China National Natural Science Foundation for funding the research project (71773091) "Resource Endowment, Proper Rights Evolution, and Forest Quality in Collective Forest Regions of China" and the research project (71403212) "Households' Behavior Choice and Efficiency Improvement 
of Non-timber Forest Products Management in Western China Based on Labour Allocation of Intra-family". We are also grateful to all other participants involved in the projects for their contribution in data collection and for constructive comments. All remaining errors are our own.

Author Contributions: Yang Ren conceived and designed the study; Yang Ren and Liu Yang performed the data collection; Liu Yang analysed the data; Yang Ren, Jari Kuuluvainen and Anne Toppinen wrote the manuscript; Shunbo Yao, Sami Berghäll, Heimo Karppinen and Caixia Xue commented on and revised the manuscript.

Conflicts of Interest: The authors declare no conflict of interest.

\section{Appendix A}

Table A1. Definition of measurement items used in the establishment of the SEM.

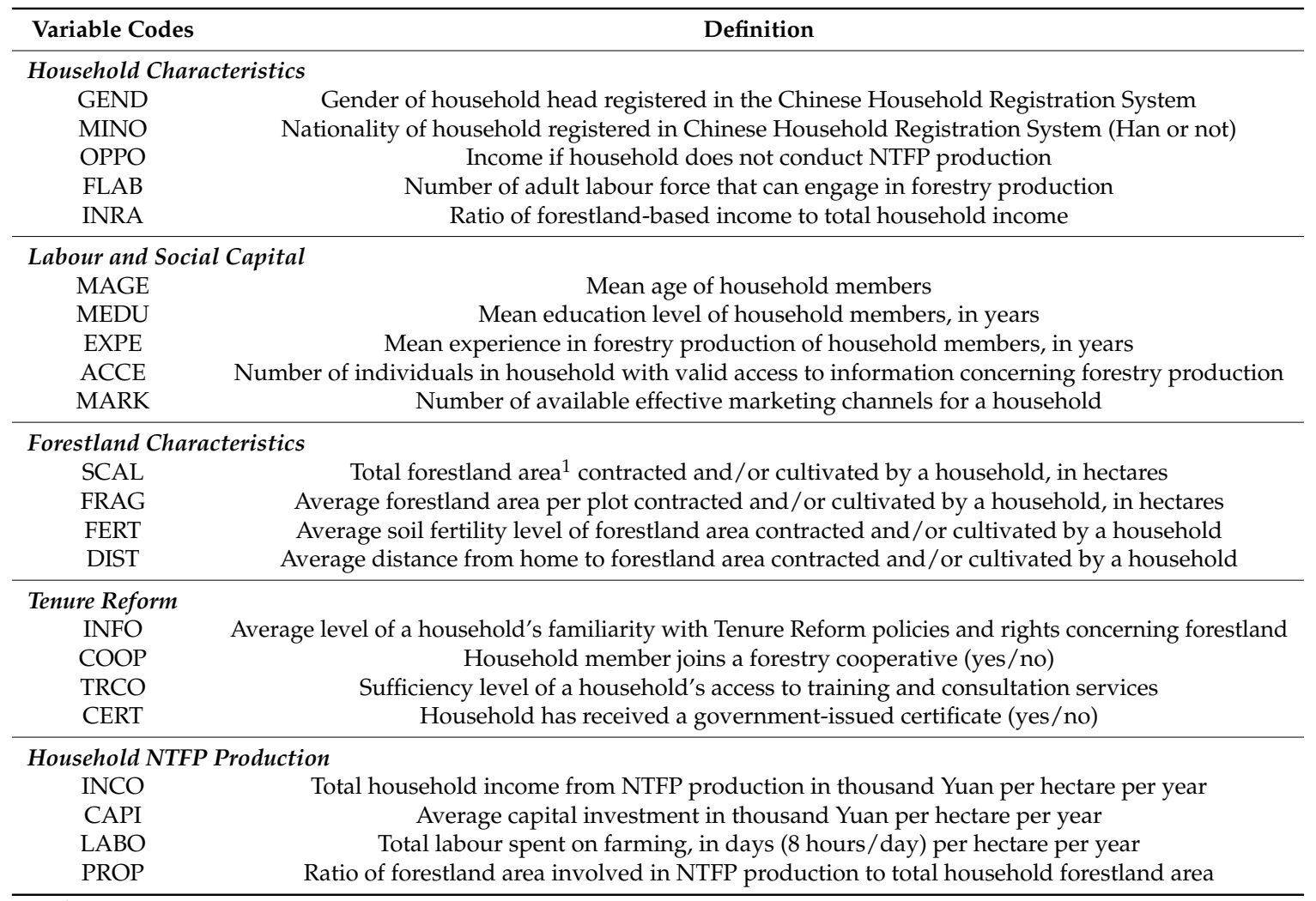

${ }^{1}$ Here, the total forestland area holding by a household includes forestland for timber and NTFP production, economic forests for short-term crop production, forests for fuelwood production, and bamboo forests. 
Table A2. Covariance matrix of the measurement items used for estimating the SEM model $(n=932)$

\begin{tabular}{|c|c|c|c|c|c|c|c|c|c|c|c|c|c|c|c|c|c|c|c|c|c|}
\hline Variable Codes & GEND & OPPO & FLAB & INRA & MAGE & MEDU & J EXPE & ACCE & MARK & SCAL & FRAG & FERT & DIST & INFO & COOP & TRCO & CERT & INCO & CAPI & LABO & PROP \\
\hline GEND & 1.481 & & & & & & & & & & & & & & & & & & & & \\
\hline OPPO & 0.582 & 1.249 & & & & & & & & & & & & & & & & & & & \\
\hline FLAB & 0.597 & 0.801 & 1.548 & & & & & & & & & & & & & & & & & & \\
\hline INRA & 0.525 & 0.782 & 0.689 & 1.371 & & & & & & & & & & & & & & & & & \\
\hline MAGE & 0.361 & 0.326 & 0.394 & 0.315 & 1.549 & & & & & & & & & & & & & & & & \\
\hline MEDU & 0.315 & 0.349 & 0.459 & 0.304 & 0.897 & 1.284 & & & & & & & & & & & & & & & \\
\hline EXPE & 0.317 & 0.408 & 0.295 & 0.289 & 0.971 & 0.617 & 1.579 & & & & & & & & & & & & & & \\
\hline ACCE & 0.148 & 0.353 & 0.284 & 0.148 & 0.576 & 0.501 & 0.517 & 1.361 & & & & & & & & & & & & & \\
\hline MARK & 0.347 & 0.405 & 0.419 & 0.410 & 0.318 & 0.381 & 0.547 & 0.841 & 1.429 & & & & & & & & & & & & \\
\hline FRAG & 0.341 & 0.457 & 0.327 & 0.341 & 0.218 & 0.256 & 0.532 & 0.651 & 0.683 & 0.739 & 1.864 & & & & & & & & & & \\
\hline FERT & 0.284 & 0.369 & 0.269 & 0.237 & 0.348 & 0.299 & 0.428 & 0.549 & 0.409 & 0.784 & 0.862 & 1.122 & & & & & & & & & \\
\hline DIST & 0.157 & 0.336 & 0.283 & 0.155 & 0.394 & 0.374 & 0.427 & 0.411 & 0.461 & 0.658 & 0.859 & 0.895 & 1.196 & & & & & & & & \\
\hline INFO & 0.152 & 0.318 & 0.270 & 0.189 & 0.293 & 0.389 & 0.483 & 0.493 & 0.398 & 0.609 & 0.856 & 0.868 & 0.871 & 1.518 & & & & & & & \\
\hline COOP & 0.193 & 0.298 & 0.264 & 0.205 & 0.281 & 0.481 & 0.543 & 0.531 & 0.374 & 0.501 & 0.841 & 0.705 & 0.697 & 0.716 & 0.989 & & & & & & \\
\hline TRCO & 0.104 & 0.276 & 0.253 & 0.149 & 0.301 & 0.358 & 0.406 & 0.412 & 0.360 & 0.416 & 0.639 & 0.659 & 0.664 & 0.649 & 0.904 & 1.521 & & & & & \\
\hline CERT & 0.113 & 0.291 & 0.190 & 0.218 & 0.289 & 0.327 & 0.351 & 0.349 & 0.395 & 0.487 & 0.551 & 0.589 & 0.625 & 0.601 & 0.865 & 0.988 & 1.987 & & & & \\
\hline INCO & 0.154 & 0.154 & 0.203 & 0.268 & 0.281 & 0.284 & 0.310 & 0.362 & 0.259 & 0.328 & 0.681 & 0.418 & 0.518 & 0.399 & 0.457 & 0.584 & 0.784 & 2.017 & & & \\
\hline CAPI & 0.149 & 0.143 & 0.217 & 0.155 & 0.318 & 0.378 & 0.315 & 0.341 & 0.294 & 0.314 & 0.397 & 0.299 & 0.314 & 0.387 & 0.347 & 0.591 & 0.748 & 0.586 & 1.851 & & \\
\hline LABO & 0.040 & 0.111 & 0.158 & 0.127 & 0.234 & 0.359 & 0.458 & 0.281 & 0.291 & 0.397 & 0.366 & 0.364 & 0.378 & 0.380 & 0.356 & 0.547 & 0.736 & 0.772 & 0.784 & 1.974 & \\
\hline
\end{tabular}




\section{References}

1. Dachang, L. Tenure and management of non-state forests in China since 1950: A historical review. Environ. Hist. 2001, 6, 239-263. [CrossRef]

2. Hyde, W.F.; Belcher, B.M.; Xu, J. China's forests: Global Lessons from Market Reforms; Resources for the Future and CIFOR: Washington, DC, USA, 2003.

3. State Forestry Administration of China (SFA). China Forestry Database. Available online: http://data. forestry.gov.cn/lysjk/indexJump.do?url=view/moudle/index (accessed on 15 August 2017).

4. Liu, C.; Lu, J.; Yin, R. An estimation of the effects of China's priority forestry programs on farmers' income. Environ. Manag. 2010, 45, 526-540. [CrossRef] [PubMed]

5. State Forestry Administration of China (SFA). China forest resource report (2009-2013); China Forestry Publishing House: Beijing, China, 2014. (In Chinese)

6. Delang, C.; Wang, W. Chinese forest policy reforms after 1998: The case of the natural forest protection program and the slope land conversion program. Int. Forest. Rev. 2013, 15, 290-304. [CrossRef]

7. Yin, R.; Zulu, L.; Qi, J.; Freudenberger, M.; Sommerville, M. Empirical linkages between devolved tenure systems and forest conditions: Primary evidence. For. Policy Econ. 2016, 73, 277-285. [CrossRef]

8. Shackleton, C.M.; Pandey, A.K.; Ticktin, T. Illustration of the effects of non-timber forest products production. In Ecological Sustainability for Non-Timber Forest Products: Dynamics and Case Studies of Harvesting; Routledge: London, UK, 2015; Volume 23, pp. 125-201.

9. Ticktin, T. The ecological implications of harvesting non-timber forest products. J. Appl. Ecol. 2004, 41, 11-21. [CrossRef]

10. Schaafsma, M.; Morse-Jones, S.; Posen, P.; Swetnam, R.D.; Balmford, A.; Bateman, I.J.; Burgess, N.D.; Chamshama, S.A.O.; Fisher, B.; Freeman, T.; et al. The importance of local forest benefits: Economic valuation of non-timber forest products in the eastern arc mountains in Tanzania. Glob. Environ. Chang. 2014, 24, 295-305. [CrossRef]

11. Shackleton, C.; Shackleton, S. The importance of non-timber forest products in rural livelihood security and as safety nets: A review of evidence from South Africa. S. Afr. J. Sci. 2004, 100, 658-664.

12. Mahapatra, A.K.; Tewari, D.D. Importance of non-timber forest products in the economic valuation of dry deciduous forests of India. For. Policy Econ. 2005, 7, 455-467. [CrossRef]

13. Dawson, I.K.; Leakey, R.; Clement, C.R.; Weber, J.C.; Cornelius, J.P.; Roshetko, J.M.; Vinceti, B.; Kalinganire, A.; Tchoundjeu, Z.; Masters, E. The management of tree genetic resources and the livelihoods of rural communities in the tropics: Non-timber forest products, smallholder agroforestry practices and tree commodity crops. For. Ecol. Manag. 2014, 333, 9-21. [CrossRef]

14. Gunatilake, H.; Senaratne, D.M.; Abeygunawardena, P. Role of non-timber forest products in the economy of peripheral communities of knuckles national wilderness area of Sri Lanka: A farming systems approach. Econ. Bot. 1993, 47, 275-281. [CrossRef]

15. Chukwuone, N.A.; Okeke, C.A. Can non-wood forest products be used in promoting household food security? Evidence from Savannah and rainforest regions of southern Nigeria. For. Policy Econ. 2012, 25, 1-9. [CrossRef]

16. Shackleton, C.M.; Pandey, A.K. Positioning non-timber forest products on the development agenda. For. Policy Econ. 2014, 38, 1-7. [CrossRef]

17. Steele, M.Z.; Shackleton, C.M.; Shaanker, R.U.; Ganeshaiah, K.; Radloff, S. The influence of livelihood dependency, local ecological knowledge and market proximity on the ecological impacts of harvesting non-timber forest products. For. Policy Econ. 2015, 50, 285-291. [CrossRef]

18. Belcher, B.; Ruíz-Pérez, M.; Achdiawan, R. Global patterns and trends in the use and management of commercial ntfps: Implications for livelihoods and conservation. World Dev. 2005, 33, 1435-1452. [CrossRef]

19. Ticktin, T.; Shackleton, C. Harvesting non-timber forest products sustainably: Opportunities and challenges. In Non-timber Forest Products in the Global Context; Shackleton, S., Shackleton, C., Shanley, P., Eds.; Springer: Berlin, Germany, 2011; Volume 7, pp. 149-169.

20. Zhang, H.; Kuuluvainen, J.; Yang, H.; Xie, Y.; Liu, C. The effect of off-farm employment on forestland transfers in China: A simultaneous-equation Tobit model estimation. Sustainability 2017, 9, 1645. [CrossRef] 
21. Chen, J.; Innes, J.L. The implications of new forest tenure reforms and forestry property markets for sustainable forest management and forest certification in China. J. Environ. Manag. 2013, 129, 206-215. [CrossRef] [PubMed]

22. Siikamäki, J.; Ji, Y.; Xu, J. Post-reform forestland markets in China. Land Econ. 2015, 91, 211-234. [CrossRef]

23. Yin, R.; Yao, S.; Huo, X. China's forest tenure reform and institutional change in the new century: What has been implemented and what remains to be pursued? Land Use Policy 2013, 30, 825-833. [CrossRef]

24. Qin, P.; Xu, J. Forest land rights, tenure types, and farmers' investment incentives in China. China Agric. Econ. Rev. 2013, 5, 154-170. [CrossRef]

25. Xie, L.Y.; Berck, P.; Xu, J.T. The effect on forestation of the collective forest tenure reform in China. China Econ. Rev. 2016, 38, 116-129. [CrossRef]

26. Xie, Y.; Gong, P.; Han, X.; Wen, Y. The effect of collective forestland tenure reform in China: Does land parcellation reduce forest management intensity? J. For. Econ. 2014, 20, 126-140. [CrossRef]

27. Zhang, H.; Buongiorno, J.; Zhu, S. Domestic and foreign consequences of China's land tenure reform on collective forests. Int. For. Rev. 2012, 14, 349-362. [CrossRef]

28. Živojinović, I.; Nedeljković, J.; Stojanovski, V.; Japelj, A.; Nonić, D.; Weiss, G.; Ludvig, A. Non-timber forest products in transition economies: Innovation cases in selected see countries. For. Policy Econ. 2017, 81, 18-29. [CrossRef]

29. Mukul, S.A.; Rashid, A.M.; Uddin, M.B.; Khan, N.A. Role of non-timber forest products in sustaining forest-based livelihoods and rural households' resilience capacity in and around protected area: A Bangladesh study. J. Environ. Plan. Manag. 2016, 59, 628-642. [CrossRef]

30. Zhu, H.; Hu, S.; Ren, Y.; Ma, X.; Cao, Y. Determinants of engagement in non-timber forest products (NTFPs) business activities: A study on worker households in the forest areas of daxinganling and xiaoxinganling mountains, Northeastern China. For. Policy Econ. 2017, 80, 125-132. [CrossRef]

31. Janse, G.; Ottitsch, A. Factors influencing the role of non-wood forest products and services. For. Policy Econ. 2005, 7, 309-319. [CrossRef]

32. Wang, W.; Li, Q.; Lien, D. Human capital, political capital, and off-farm occupational choices in rural China. Int. Rev. Econ. Finance 2016, 42, 412-422. [CrossRef]

33. Zhang, D.; Aboagye Owiredu, E. Land tenure, market, and the establishment of forest plantations in Ghana. For. Policy Econ. 2007, 9, 602-610. [CrossRef]

34. Ndoye, O.; Pérez, M.R.; Eyebe, A. The Markets of Non-Timber Forest Products in the Humid Forest Zone of Cameroon; Overseas Development Institute: London, UK, 2016.

35. Liu, S.; Chen, G.; Huang, H.; Lin, W.; Guo, D.; Zhao, S.; Tian, D.; Su, M. Patrilineal background of the minority population from Chaoshan Fenghuang mountain, an isolated mountain region, in China. Genomics 2017, 109, 284-289. [CrossRef] [PubMed]

36. Senaratne, A.; Abeygunawardena, P.; Jayatilake, W. Changing role of non-timber forest products (NTFP) in rural household economy: The case of Singaraja world heritage site in Sri Lanka. Environ. Manag. 2003, 32, 559-571. [CrossRef] [PubMed]

37. Dongliang, Z.; Jia, X. The reform of the collectively-owned forestry system in Fujian: Implementation, effects and reflection. J. China Agric. Univ. 2007, 3, 12-21. (In Chinese)

38. Xie, Y.; Wen, Y.; Zhang, Y.; Li, X. Impact of property rights reform on household forest management investment: An empirical study of southern China. For. Policy Econ. 2013, 34, 73-78. [CrossRef]

39. Arnold, J.E.M. Economic Factors in Farmer Adoption of Forest Product Activities. Available online: http:/ /www.fao.org/docrep/w3735e/w3735e19.htm (accessed on 4 April 2018).

40. Fu, Y.; Chen, J.; Guo, H.; Chen, A.; Cui, J.; Hu, H. The role of non-timber forest products during agroecosystem shift in Xishuangbanna, southwestern China. For. Policy Econ. 2009, 11, 18-25. [CrossRef]

41. López-Feldman, A.; Wilen, J.E. Poverty and spatial dimensions of non-timber forest extraction. Environ. Dev. Econ. 2008, 13, 621-642. [CrossRef]

42. Burton, R.J. An alternative to farmer age as an indicator of the life-cycle stage: The case for a farm family age index. J. Rural Stud. 2006, 22, 485-492. [CrossRef]

43. Liu, C.; Mullan, K.; Liu, H.; Zhu, W.; Rong, Q. The estimation of long-term impacts of China's key priority forestry programs on rural household incomes. J. For. Econ. 2014, 20, 267-285. [CrossRef]

44. Wei, D.; Chao, H.; Yali, W. Role of income diversification in reducing forest reliance: Evidence from 1838 rural households in China. J. For. Econ. 2016, 22, 68-79. [CrossRef] 
45. Xu, J. Collective Forest Tenure Reform in China: What Has Been Achieved So Far; World Bank Conference on Land Governance: Washington, DC, USA, 2010.

46. Stoian, D. Making the best of two worlds: Rural and peri-urban livelihood options sustained by nontimber forest products from the Bolivian Amazon. World Dev. 2005, 33, 1473-1490. [CrossRef]

47. Ndayambaje, J.; Heijman, W.; Mohren, G. Household determinants of tree planting on farms in rural Rwanda. Small Scale For. 2012, 11, 477-508. [CrossRef]

48. Tilt, B.; Gerkey, D. Dams and population displacement on China's upper Mekong River: Implications for social capital and social-ecological resilience. Glob. Environ. Chang. 2016, 36, 153-162. [CrossRef]

49. Ray, D. Development Economics; Princeton University Press: Princeton, NJ, USA, 1998.

50. Tuff, K.; Tuff, T.; Davies, K. A framework for integrating thermal biology into fragmentation research. Ecol. Lett. 2016, 19, 361-374. [CrossRef] [PubMed]

51. Zhang, K.; Song, C.; Zhang, Y.; Zhang, Q. Natural disasters and economic development drive forest dynamics and transition in China. For. Policy Econ. 2017, 76, 56-64. [CrossRef]

52. Xuemei, X.J.S.Y.J.; Jie, L. Collective forest tenure reform in China: Analysis of pattern and performance. Forest. Econ. 2008, 9, 7-15. (In Chinese)

53. He, J.; Dong, M.; Stark, M. Small mushrooms for big business? Gaps in the sustainable management of non-timber forest products in southwest China. Sustainability 2014, 6, 6847-6861. [CrossRef]

54. Jintao, J.X.L.L.X. Impact analysis of tenure reform on forest management model in plain forest area-Investigation report of forest tenure reform in Shandong Province. For. Econ. 2008, 10, 11-18.

55. Yi, Y.; Köhlin, G.; Xu, J. Property rights, tenure security and forest investment incentives: Evidence from China's collective forest tenure reform. Environ. Dev. Econ. 2014, 19, 48-73. [CrossRef]

56. Bass, S. Certification's Impacts on Forests, Stakeholders and Supply Chains; Russell Press: Nottingham, UK, 2001.

57. Meishan Forestry Bureau (MFB). Meishan Forestry Production Report (2015-2016); Meishan Bureau of Statistics: Meishan, China, 2017. (In Chinese)

58. Bollen, K.A. A new incremental fit index for general structural equation models. Sociol. Methods Res. 1989, 17, 303-316. [CrossRef]

59. Schumacker, R.E.; Lomax, R.G. A Beginner's Guide to Structural Equation Modeling; Psychology Press: New York, NY, USA, 2004.

60. Aibinu, A.A.; Al-Lawati, A.M. Using pls-sem technique to model construction organizations' willingness to participate in e-bidding. Autom. Construct. 2010, 19, 714-724. [CrossRef]

61. Hair, J.F., Jr.; Hult, G.T.M.; Ringle, C.; Sarstedt, M. A Primer on Partial Least Squares Structural Equation Modeling; Sage Publications: London, UK, 2016.

62. Muthén, B. A general structural equation model with dichotomous, ordered categorical, and continuous latent variable indicators. Psychometrika 1984, 49, 115-132. [CrossRef]

63. Maruyama, G. Basics of Structural Equation Modeling; Sage Publications: London, UK, 1997.

64. Fornell, C.; Larcker, D.F. Evaluating structural equation models with unobservable variables and measurement error. J. Market. Res. 1981, 18, 39-50. [CrossRef]

65. Nachtigall, C.; Kroehne, U.; Funke, F.; Steyer, R. (Why) Should We Use SEM? Pros and cons of structural equation modelling. Methamphetamine Psychol. Res. 2003, 8, 1-22.

66. Hu, L.; Bentler, P.M. Cutoff criteria for fit indexes in covariance structure analysis: Conventional criteria versus new alternatives. Struct. Equ. Model. 1999, 6, 1-55. [CrossRef]

67. Sisak, L.; Riedl, M.; Dudik, R. Non-market non-timber forest products in the Czech Republic-Their socio-economic effects and trends in forest land use. Land Use Policy 2016, 50, 390-398. [CrossRef]

68. Wu, Z.; Ge, Q.; Dai, E. Modeling the relative contributions of land use change and harvest to forest landscape change in the taihe county, China. Sustainability 2017, 9, 708. [CrossRef]

69. Liu, C.; Liu, H.; Wang, S. Has China's new round of collective forest reforms caused an increase in the use of productive forest inputs? Land Use Policy 2017, 64, 492-510. [CrossRef]

70. Zhu, Z.; Shen, Y.; Lü, Q.; Zheng, X. An empirical study on input and causal factors of non-timber forest production. J. Nat. Resour. 2011, 2, 2-10. (In Chinese)

71. Food and Agriculture Organization of the United Nations (FAO). Non-Wood Forest Products for Rural Income and Sustainable Forestry. Available online: http:/ /www.fao.org/docrep/v9480e/v9480e00.htm (accessed on 29 March 2018). 
72. Sainz, R.C.; Tome, M.; Sánchez-González, M.; Miina, J.; Spanos, K.; Palahi, M. Modelling non-wood forest products in Europe: A review. For. Syst. 2010, 19, 69-85.

73. Abraham, E.; Theodoropoulos, K.; Eleftheriadou, E.; Ragkos, A.; Kyriazopoulos, A.; Parissi, Z.; Arabatzis, G.; Soutsas, K. Non-wood forest products from the understory and implications for rural development: The case of a broadleaf deciduous oak forest in Chalkidiki, Greece. J. Environ. Protect. Ecol. 2015, 16, 1024-1032.

(c) (1)

(C) 2018 by the authors. Licensee MDPI, Basel, Switzerland. This article is an open access article distributed under the terms and conditions of the Creative Commons Attribution (CC BY) license (http://creativecommons.org/licenses/by/4.0/). 